\title{
Habitat, breeding performance, diet and individual age in Swiss Barn Owls (Tyto alba)
}

\author{
Caroline Frey • Caroline Sonnay • Amélie Dreiss • \\ Alexandre Roulin
}

Received: 22 April 2010/Revised: 30 July 2010/Accepted: 24 August 2010/Published online: 9 September 2010

(C) Dt. Ornithologen-Gesellschaft e.V. 2010

\begin{abstract}
Intensification of farming over the past 50 years has homogenised the landscape structure and contributed to the decline of bird populations in Europe. To better target the conservation of the Barn Owl Tyto $a l b a$, we assessed the influence of the landscape structure on breeding performance in western Switzerland. The analyses considered a 23-year dataset of breeding parameters collected in an area dominated by intensive agriculture. Using a Geographic Information System approach, landscape characteristics were described around 194 nest sites. Our analyses showed that nest-box occupancy, laying date, clutch and brood size, egg volume and probability of producing a second annual clutch were not significantly associated with any of the eight principal landscape variables (agricultural land, woodland, urban area, hedgerows, cereals, sugar beet, maize and meadow). Nevertheless, the probability that a breeding pair occupied a nest-box decreased the more roads there were surrounding the nestbox. The absence of strong associations between habitat features and breeding parameters suggests that prey availability may be relatively similar between the different breeding sites. In our study area, Barn Owls can always find suitable foraging habitats around most nest-boxes.
\end{abstract}

Keywords Conservation biology - Landscape structure . Home range habitat - Habitat preference - GIS · Tyto alba

Communicated by F. Bairlein.

C. Frey · C. Sonnay · A. Dreiss · A. Roulin $(\bowtie)$

Department of Ecology and Evolution, University of Lausanne, Biophore, 1015 Lausanne, Switzerland

e-mail: Alexandre.Roulin@unil.ch

\section{Introduction}

Changes in agricultural systems over the past 50 years have led to an important modification of the rural landscape. The intensification of farming has contributed to the decline of species richness in several taxa in many European countries (Benton et al. 2003; Billeter et al. 2008; Stoate et al. 2009) and notably in farmland bird species (Donald et al. 2001; Newton 2004). In order to reverse this trend, great efforts are being made to understand the effect of landscape on species ecology and to enable effective management and conservation (for small mammals: de la Pena et al. 2003; Michel et al. 2006; for birds: Tworek 2002; Seamans and Gutierrez 2007).

The Barn Owl (Tyto alba) has a worldwide distribution range (Taylor 1994), and populations have declined since the middle of the twentieth century in most European countries and notably in Switzerland (Maumary et al. 2007). Since the 1980s, Barn Owl populations have partially recovered but without reaching initial sizes (Maumary et al. 2007), and the species is still threatened (Keller et al. 2001). The main reason explaining the decline in population size is the intensification of farming practices causing a reduction of the quality of foraging habitats and nest sites, the two key factors determining Barn Owl population dynamics (De Bruijn 1994; Taylor 1994; Roulin 2002a). A major component of habitat quality is the abundance and accessibility of small mammals living in open fields (Klok and de Roos 2007), factors that depend on the landscape pattern (Rodriguez and Peris 2007). Barn Owls usually forage in open and extensively cultivated farmland containing linear structures such as woodland edges, river banks, hedgerows and crop margins (Andries et al. 1994; Martinez and Zuberogoitia 2004; Kasprzykowski and Golawski 2006). These linear structures are common 
forms of ecological compensation areas and produce biomass for predators (Aschwanden et al. 2007; Butet et al. 2006). However, recent studies have revealed that prey accessibility may play a more crucial role than prey density in the choice of foraging habitats by Swiss Barn Owls and Long-eared Owls (Asio otus), and typically, small mammals present in ecological compensation areas are not accessible to owls (Arlettaz et al. 2010; Aschwanden et al. 2005). In order to better orientate the conservation of the Barn Owl, we have to identify to what extent landscape structures contribute to breeding success. The choice of barns for nest-boxes and the creation of open foraging corridors within ecological compensation areas could participate in restoring Barn Owl populations (Arlettaz et al. 2010).

The development of new image processing techniques such as Geographical Information Systems (GIS), and the use of more precise aerial and satellite images, has expanded the spatial perception of ecological landscape research. These methods have been tested and have shown their effectiveness as a powerful tool for studying habitat preferences of birds (Andries et al. 1994; Garcia-Ripolles et al. 2005; Lopez-Lopez et al. 2006). Several studies using these techniques have been performed on Barn Owls. Salvati et al. (2002) compared habitat features around breeding sites, reproductive success and feeding habits from urban versus rural areas in central Italy. Their results have confirmed that, in both habitats, open land represented the main foraging habitat, but no significant difference was found between the breeding success of owls living in urban versus rural areas. In southern England, Bond et al. (2005) showed that successful sites had less heterogeneous land cover, grassland, suburban and wetlands than unsuccessful sites. However, the landscape scale used to identify the different habitats was not detailed enough to gain a good assessment of mosaic habitats. In a long-term study in England, Meek et al. (2009) found no relationship between habitat characteristics and breeding success, and therefore concluded that Barn Owls are rather adaptable to their environment and do not seem to be strongly dependent on the habitats of its major prey.

The aim of our study performed in western Switzerland is to assess the relationship between habitat features and breeding performance (i.e. laying date, clutch and brood size, and egg volume) of Barn Owls. The analyses considered a 23-year dataset collected in an area dominated by intensive agriculture. Using a GIS approach, landscape characteristics were described in spring 2009 around each nest site monitored over the last 23 years. Pellet analyses were performed to test the assumption that the landscape characteristics are associated with diet, and therefore, with the relative abundance of the major prey species.

\section{Materials and methods}

Study area and reproductive parameters

The study was carried out in an area covering $560 \mathrm{~km}^{2}$ at an altitude of 430-730 m (Fig. 1). This zone contains two ancient marshy plains (Broye and Orbe plains) in its centre, which are dominated by intensive agriculture at the present time.

A total of 194 nest-boxes were placed on barns progressively from 1985 to 2008 . During the 23 years from 1987 to 2009 , the nest-boxes were regularly visited during the breeding season to determine whether they were occupied or not by a breeding pair. Each year, we defined a nest-box as 'occupied' if at least one Barn Owl egg had been laid. The following breeding parameters were recorded: the laying date, clutch size, hatching success, mean egg volume (egg length $\times$ egg width $\left.{ }^{2} \times \pi / 6\right)$ and number of fledglings. The laying date is the date when the first egg of each clutch was laid, determined from the length of the flattened wing from the bird's wrist to the tip of the longest primary of the first-hatched nestling and assuming a period of 32 days for incubation (Roulin 2004a). For the analysis of the clutch size, we included nests containing at least one egg and that were not abandoned before clutch completion. As Barn Owls do not evict non-hatched eggs from their nest, brood size at hatching is defined as clutch size minus the number of non-hatched eggs. All nests were visited when nestlings were 55 days of age to record brood size at fledging. Most breeding adults were captured $(80 \%$ for males and $94 \%$ for females) and ringed with a numbered

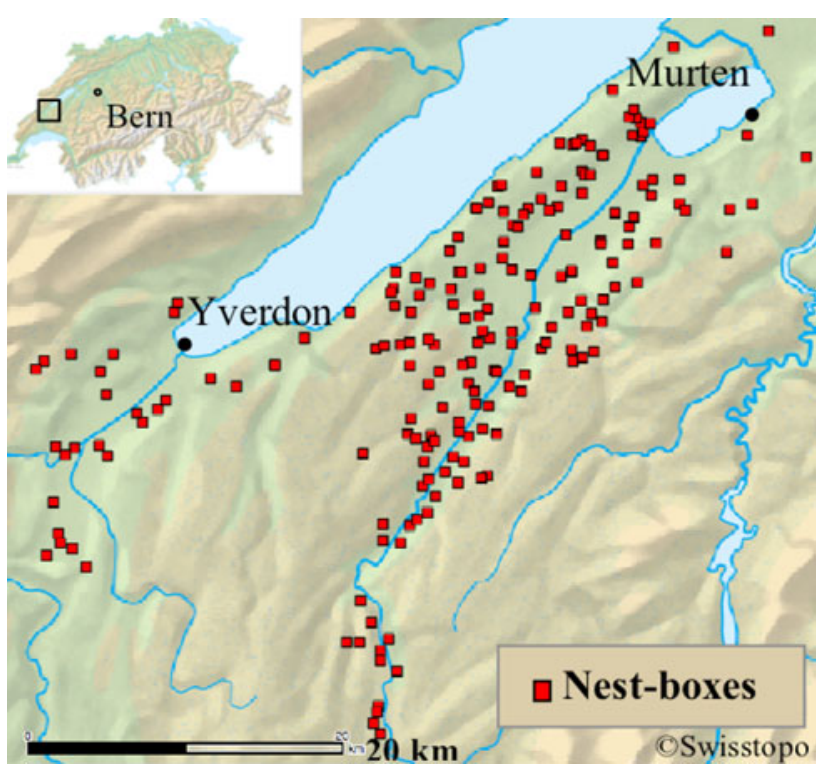

Fig. 1 Location of the study area in Switzerland. Coordinates of central area are $46^{\circ} 49^{\prime} \mathrm{N}, 06^{\circ} 56^{\prime} \mathrm{E}$. Each dot indicates a nest-box available to breeding Barn Owls (Tyto alba) 
aluminium band to determine whether a given reproductive event was a first or second annual breeding attempt. About $10 \%$ of individuals produce a second annual clutch (Altwegg et al. 2007) and often in a different nest-box as the one where the first annual clutch was produced (Roulin 2002b). The age of the breeding birds was known from re-captured individuals ringed as nestlings, otherwise age was estimated by the moult pattern (Taylor 1993).

\section{Landscape characteristics}

To describe the environment surrounding each of the 194 nest-boxes, we defined radiuses of $0.75 \mathrm{~km}$ (surface area $=176$ hectares), $1 \mathrm{~km}$ (314 ha) and $1.5 \mathrm{~km}$ (706 ha) from nesting sites. We chose these sizes because they correspond respectively to the minimum (93 ha), mean (335 ha) and maximum (804 ha) home range of seven breeding males radio-tagged in 2005 in the same study area (Arlettaz et al. 2010). We classified the landscape around the nest-sites into different habitat characteristics with a Geographic Information System software (ArcGIS 9.2, Environmental Systems Research Institute, Inc., Redlands, California, United States), using aerial orthophotographs $(0.5 \mathrm{~m}$ resolution; Federal Office of Topography SwissTopo DV084371, 2004). The total areas of the following nine habitats were extracted: woodland, urban area, hedgerows, main river, orchard, vineyard, water surface (lakes and ponds), swamp and agricultural land. In summer 2009, we identified $93 \%$ of the agricultural land as the following arable fields: cereals (winter wheat, barley, rye, triticale, oat), sugar beet, meadow, maize, tobacco, sunflower, potato, colza, pea, wildflower area and market gardening. Wildflower areas form a part of ecological compensation areas in Switzerland and are managed setasides where seeds of wild flowers are sown. Meadows include intensive meadows (fertilised grasslands that are part of the crop rotation) and pastures. The boundary lines ("perimeter") of each class of habitat were also extracted and represent for example banks of rivers or edges of forests. The total length of the perimeter of all the habitat classes gave an index of landscape heterogeneity. Two other variables linked to the habitat environment were defined: the altitude above sea level of the barn containing the nest-box and the total length of all the roads inside a radius of $0.75 \mathrm{~km}$ around each nest-box.

\section{Barn Owl diet}

Pellet analysis gives information not only on the diet of the Barn Owl (e.g. Bontzorlos et al. 2005; Love et al. 2000), but also on habitat quality (de la Pena et al. 2003) and prey abundance (Avenant 2005). An association between the proportion of the different prey species found in the diet and the landscape variables would indicate that our landscape measures reflect foraging habitat and food accessibility. In 2009, all the nest-boxes were cleaned twice before collecting pellets, once during the winter 2008-2009 and a second time after the nestlings hatched in spring/summer 2009. We collected the pellets between August and November 2009 in 20 nest-boxes where at least one egg had hatched. Consequently, our analyses of pellets provided information on the diet during the nestling period. Prey species were identified following the analysis of bones (Chaline et al. 1974). For each prey species, we calculated its proportion in the diet as the ratio of the number of individuals of this species found in pellets divided by the total number of identified prey items.

\section{Selection of habitat variables}

In order to simplify the analyses, we eliminated from the dataset landscape variables with an area below $5 \%$ of the total area. This includes orchard, water surface, vineyard, river, swamp, colza, potato, tobacco, pea, market gardening, sunflower and wildflower areas. In preliminary analyses, none of these variables were associated with breeding parameters. Therefore, for subsequent analyses we retained four habitat features (woodland, agricultural land, urban area, hedgerows), four crops (cereals, sugar beet, maize, meadow) and the total perimeter of all habitat classes (i.e. also including the variables which had an area below $5 \%$ of the total area). For each variable, the area and perimeter were highly correlated (Pearson's correlations: $r=0.65-0.93$, $P<0.001$ ). Because we obtained similar results when considering the area or perimeters, we will present only the analyses including area variables. Furthermore, the statistical analyses were carried out on the data of the three radiuses of $0.75,1.0$ and $1.5 \mathrm{~km}$ centred on the nesting sites. The results were similar because of the high correlation of the habitat variables between these radiuses (Pearson's correlations: $r=0.45-0.97, P<0.001$ ). Consequently, we only present the results based on the radius of $1.0 \mathrm{~km}$, which corresponds to the mean home range of male Barn Owls in our study area (Arlettaz et al. 2010).

All statistical analyses were done with the software JMP 7.0 (SAS Institute, Cary, NC, USA) except GLIMMIX with SAS. We obtained indices of habitat characteristics out of the nine environmental variables and altitude by extracting the three-first components of a principal components analysis (PCA) based on the correlation matrix. This was necessary to reduce the number of tests and also because some environmental variables are highly correlated among each other with Pearson's correlation coefficients $\leq 0.73$. The three-first principal components explained $72 \%$ of the variability (Table 1) and are hereafter referred to as 'habitat components'. We did not introduce 
Table 1 Principal components analysis on the eight main environmental variables, altitude of nest-boxes and the total perimeter (sum of perimeters of all landscape classes) measured within a radius of $1.0 \mathrm{~km}$ around each Barn Owl (Tyto alba) nest-box

\begin{tabular}{lrrr}
\hline Habitat variables & \multicolumn{3}{c}{ Principal components } \\
\cline { 2 - 4 } & \multicolumn{1}{c}{ HC1 } & HC2 & HC3 \\
\hline Altitude & -0.31 & 0.36 & 0.26 \\
Total perimeter & 0.04 & 0.52 & -0.17 \\
Hedgerow area & 0.09 & 0.36 & -0.42 \\
Woodland area & -0.45 & -0.12 & 0.28 \\
Agricultural land area & 0.42 & 0.30 & 0.28 \\
Urban area & 0.07 & -0.14 & -0.67 \\
Sugar beet area & 0.44 & -0.14 & 0.15 \\
Maize area & 0.33 & 0.12 & 0.01 \\
Meadow area & -0.16 & 0.54 & 0.05 \\
Cereal area & 0.41 & -0.02 & 0.30 \\
Eigenvalue & 3.55 & 2.16 & 1.57 \\
Cumulative variance & 0.35 & 0.57 & 0.72 \\
\hline
\end{tabular}

Loadings of the three-first principal components, referred to as habitat components (HC) were extracted and used in mixed models analyses

the total length of all roads in the principal components analysis because in preliminary analyses it appeared that it was the single habitat variable that accounted for variation in breeding parameters.

\section{Statistical analyses}

We investigated whether habitat components are associated with the probability that a nest-box was occupied by a breeding pair in a given year, the laying date, mean egg volume, clutch size, number of hatchlings and number of fledglings. The model with nest-box occupancy considered the first and second annual clutches as well as replacement clutches. The other analyses were carried out using only the first breeding attempts. Linear mixed models were used to analyse the relationship between breeding parameters and the three habitat components. Each breeding parameter was entered as dependent variable in separate models. As we often had more than one measure per individual, per year and per nest-box, these three variables were incorporated as random factors in models to control for nonindependence of the data. We did not nest the individual factor in 'year' or 'nest-box' because an individual that bred several times did not always do so in the same year or in the same nest-box. Some variables that could interact with breeding success were also introduced in models as covariates, in addition to the three habitat components. In all models, we introduced the number of years a nest-box was available (referred to as 'nest-box age') and the two geographic coordinates of each nest-box as well as their interaction to control for the possibility that the different habitats are non-randomly distributed within the study area. For the analysis of site occupancy, we also introduced as covariate whether a breeding pair already occupied the site the year before ('used the year before'). For the analyses of laying date, clutch size, hatch size, number of fledglings and mean egg volume, we took into account the age of breeding individuals because the Barn Owl reproductive success changes with age (Altwegg et al. 2007), and whether individuals bred in the site in the past ['occupancy': $1=$ first reproduction in the site $(433$ males and 609 females); 2 = have already bred in the site the year before (270 males and 208 females); $3=$ have already bred in the site but not the year before ( 33 males and 25 females)], because owls that already know their home range may better exploit it than newcomers. Finally, we also introduced the laying date as covariate for the analysis of clutch size, hatch size, number of fledglings and mean egg volume, as laying date influences other breeding parameters (Roulin 2002a).

A model was performed to analyse the probability that a second annual clutch is produced in a given nest-box that was used by a pair to produce a first annual clutch; in this model, we included the three habitat components that describe the environment surrounding the nest-box and, as covariates the number of first clutches produced since the beginning of the study, the number of years a nest-box was available and the geographic coordinates. For individuals that switched nest-boxes between the first and second annual clutches, we compared habitat characteristics of these two sites with a signed-rank test. Using a paired $t$ test we compared the clutch size, mean egg volume and number of fledglings produced at the first and second annual clutches by individual females.

Statistical analyses were performed on the proportion of the commonest prey species found in the diet (i.e. common voles Microtus arvalis, water voles Arvicola terrestris and wood mice Apodemus spp.; Table 2). These proportions were introduced as dependent variables in separate mixed models. Because we had data on diet for only 20 nest-boxes, we limited the number of explanatory variables to the most relevant ones including the laying date, altitude, and areas of woodland, agricultural land, cereals and hedgerows. To simplify the analysis on such a low number of nests, we used the stepwise procedure with the probability of leaving a factor being set to 0.10 .

Variables were considered significant if the corresponding $P$ value of two-tailed tests is lower than 0.05 . Non-significant interactions and variables not involved in significant interactions were removed from the final model. Assumptions for the parametric tests used (homoscedastic and normal distributions of variables or residuals) were verified in each test. Degrees of freedom can differ 
Table 2 Prey species found in Barn Owl pellets collected in 20 nest-boxes during the breeding season in 2009
Absolute number of preyed individuals is reported as well as percentages (mean and standard deviation between sites) with regard to the total number of prey items identified $(n=7,389)$. We also report the number of nest-boxes where we found each prey species

\begin{tabular}{lrrrr}
\hline Species & Nb sites & $n$ & \multicolumn{2}{c}{ Percentage (\%) } \\
\cline { 2 - 6 } & & & Mean & SD \\
\hline Mammals & & & & \\
Common vole (Microtus arvalis) & 20 & 5,543 & 74.3 & 14.2 \\
Water vole (Arvicola terrestris) & 20 & 803 & 11.1 & 8.0 \\
Wood mouse (Apodemus spp.) & 20 & 547 & 7.0 & 4.6 \\
Crocidurinae shrew (Crocidura spp.) & 20 & 260 & 3.9 & 3.2 \\
Crowned or common shrew (Sorex araneus/coronatus) & 15 & 113 & 1.8 & 3.9 \\
Field vole (Microtus agrestis) & 8 & 29 & 0.4 & 0.6 \\
Bank vole (Clethrionomys glareolus) & 10 & 25 & 0.3 & 0.6 \\
Pygmy shrew (Sorex minutus) & 5 & 10 & 0.2 & 0.5 \\
Black rat (Rattus rattus) & 1 & 3 & 0.1 & 0.2 \\
Common dormouse (Muscardinus avellanarius) & 4 & 6 & 0.1 & 0.2 \\
Water shrew (Neomys fodiens) & 4 & 5 & 0.1 & 0.1 \\
House mouse (Mus musculus) & 1 & 5 & 0.04 & 0.2 \\
Common mole (Talpa europea) & 1 & 1 & 0.03 & 0.1 \\
Bat (Pipistrellus nathusii) & 1 & 1 & 0.01 & 0.04 \\
Others & & & & 0.1 \\
Birds & 11 & 36 & 0.5 & 1.1 \\
Frogs & 2 & 2 & 0.03 & 0.1 \\
\hline
\end{tabular}

between analyses because we removed non-significant variables from the final models. Means are quoted \pm 1 SD.

\section{Results}

Breeding parameters

During the 23 years of study, 1,035 clutches were recorded, including 912 females producing their first annual clutches, 95 females producing their second annual clutches and 28 females producing a replacement clutch. Between 1987 and 2009, 530 different breeding females and 382 different breeding males were caught in the nest-boxes. First annual clutches were laid from 24 February to 5 August (mean is 23 April; Fig. 2), second annual clutches from 17 May to 8 August (mean is 30 June; Fig. 2) and replacement clutches from 3 April to 25 July (mean is 2 June). The number of eggs per first annual clutch ranged from 2 to 11 (mean is $5.94 \pm 1.40$ eggs; $n=780$; Fig. 3), per second annual clutch from 4 to 11 (mean is $7.10 \pm 1.59$ eggs; $n=77$; Fig. 3) and per replacement clutches from 3 to 10 (mean is $6.75 \pm 1.71$ eggs; $n=20$ ). The size of the first annual clutch is significantly lower than the size of the second annual clutch $(5.75 \pm 1.48$ vs $7.05 \pm 1.58$ eggs; paired $t$ test comparing clutch size produced by the same females at their first and second annual breeding attempt: $t_{75}=6.39$, $P<0.0001)$. Clutch size was positively correlated with the laying date (mixed model with clutch size as dependent

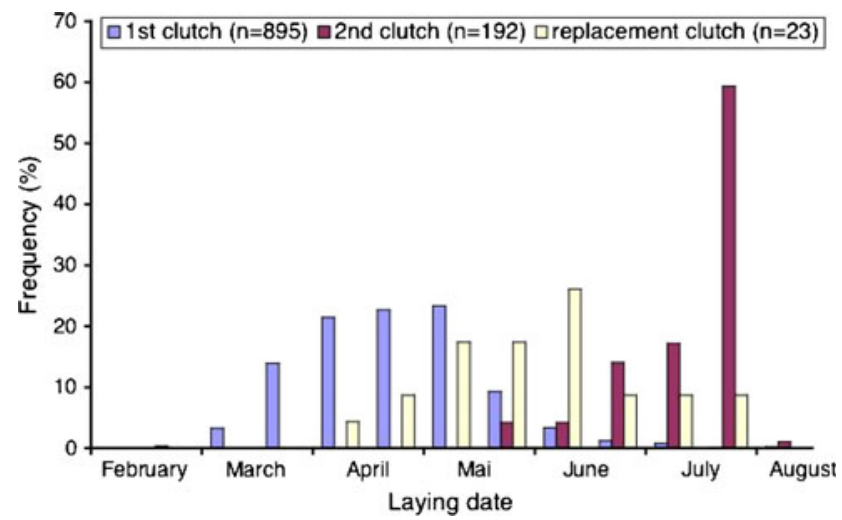

Fig. 2 Frequency distribution of the laying dates for the first and the second annual breeding attempts and the replacement clutches of Barn Owls between 1990 and 2009 in western Switzerland. The frequency $(\%)$ was calculated twice a month: from the 1 st to the 15 th and from the 16th to the end of the month

variable and year and female identity as two random variables; laying date: $\left.F_{1,671.3}=42.27, P<0.0001\right)$. Mean egg volume varied from 14.66 to $26.09 \mathrm{~cm}^{3}$ (mean is $19.30 \pm 0.02 \mathrm{~cm}^{3}, n=3,843$ eggs). The mean egg volume per clutch was not significantly correlated with the laying date (Table 3) and did not differ between first and second annual clutches (paired $t$ test: $t_{45}=-1.27, P=0.21$ ). In nest-boxes where at least one egg hatched successfully, up to 11 eggs could hatch (mean is $5.67 \pm 1.54$ eggs, $n=818$ ). Hatching success (\% of eggs which hatched in a nest) was neither associated significantly with the laying date 


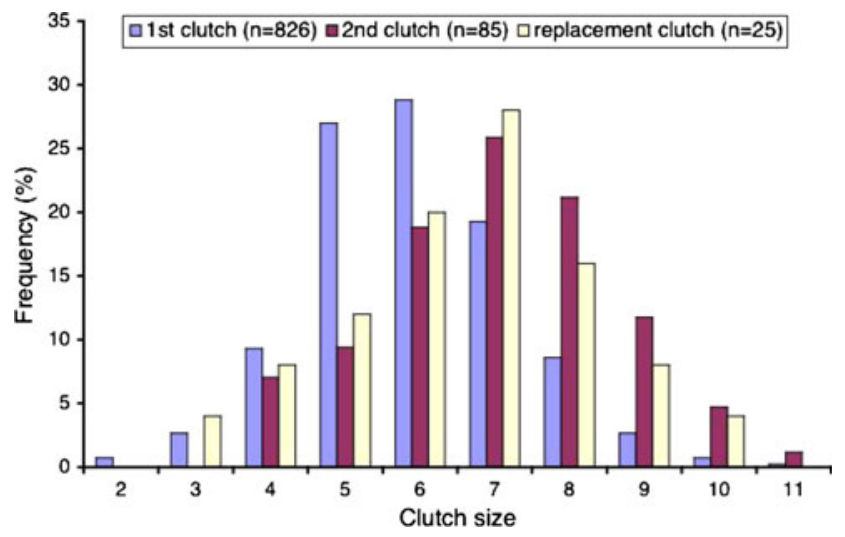

Fig. 3 Frequency distribution of the size of the first and second annual clutches and the replacement clutches in Barn Owls studied from 1987 to 2009 in western Switzerland

(Spearman's correlation by calculating mean values per individual females to avoid pseudo-replication, $r_{\mathrm{s}}=-0.03$, $n=460, P=0.48)$ nor with clutch size $\left(r_{\mathrm{s}}=-0.09\right.$, $n=460, P=0.06$ ). In nest-boxes where at least one nestling fledged successfully, between 1 and 9 nestlings took their first flight, with significantly different means of $3.98 \pm 1.68$ and $3.07 \pm 2.12$ nestlings per first and second annual clutches, respectively (paired $t$ test comparing number of fledglings produced by the same females at their first and second annual breeding attempt: $t_{84}=-3.06$, $P=0.003)$. The number of fledglings decreased with the laying date and increased with clutch size (mixed model with brood size at fledging as dependent variable and year and female identity as two random variables; laying date: $F_{1,738.5}=67.55, \quad P<0.0001 ; \quad$ clutch size: $F_{1,632.1}=$ 125.02, $P<0.0001)$.

$11.9 \%$ of the first annual clutches did not produce any fledglings (106 out of 893 clutches failed to produce a single fledgling). The percentage of failure was slightly higher, $18.9 \%$, for the second annual clutches (17 out of 90 clutches; chi-square test: $\left.\chi_{1}^{2}=2.18, \quad P=0.14\right)$, and attained $21.4 \%$ for the replacement clutches ( 6 out of 28 clutches).

\section{Environmental variables}

The area was dominated by agricultural lands (73\%), woodlands $(14.9 \%)$, urban areas $(7.4 \%)$ and hedgerows $(5.7 \%)$. All the other environmental variables represented less than $5 \%$ of the total area: orchards $(1.4 \%)$, water surface $(0.6 \%)$, vineyards $(0.4 \%)$, rivers $(0.3 \%)$ and swamps $(0.3 \%)$. The most common farming fields determined in 2009 were meadows $(35.3 \%)$, cereals $(31.3 \%)$, maize $(13.4 \%)$ and sugar beets $(7.9 \%)$ followed by colza (5.4\%), potato (2.9\%), tobacco $(1.7 \%)$, pea $(0.8 \%)$, market gardening $(0.5 \%)$, sunflower $(0.4 \%)$ and wildflower areas $(0.4 \%)$.
Barn Owl diet

A total of 7,389 individual prey items and 13 species of small mammals were identified in 20 nest-boxes that produced at least one nestling in 2009 (Table 2). We found 1 bat, 11 birds and 2 frogs but no invertebrates. A mean of 370 individual prey items was found per nest-box (range 91-733). The percentage of common voles (M. arvalis) was higher in nest-boxes located in habitats including more cereal fields $\left(F_{1,15}=14.52, P=0.0017\right)$ after controlling for the laying date $\left(F_{1,15}=5.70, P=0.03\right.$; the proportion of common voles increased with date). Water voles (A. terrestris) showed the opposite trend being negatively correlated with cereal fields $\left(F_{1,15}=13.30, P=0.0024\right.$; laying date: $F_{1,15}=5.73, P=0.03$, the proportion of water voles decreased with date). The landscape variables were not significantly associated with the percentage of wood mice (Apodemus spp.). The laying date, clutch size, mean egg volume, number of hatchlings and of fledglings were not significantly associated with the percentage of common voles, wood mice and water voles (Pearson's correlations: $P$ values $>0.19$ ).

Relationships between breeding parameters and environmental variables

For all the different mixed models, habitat components were removed before the final model (Table 3) indicating that all landscape variables were not significantly associated with breeding parameters. Some covariates were significantly associated with breeding parameters. The first annual clutch size, number of hatchlings and number of fledglings increased with female age whereas the number of hatchlings decreased with male age (Table 3). Pairs with older males laid their eggs earlier in the season (Table 3). Among first annual clutches, clutch size increased with date (Table 3). The likelihood of a nest-box being occupied increased if present in the barn for a long time and if already used the year before by a breeding pair (Table 3). Pairs that bred a second consecutive year in the same site laid their first annual clutch earlier in the season than if they were new comers (in this analysis we controlled the age of the individuals) (Table 3). Moreover, the clutch size was smaller if the male had already bred in the site the year before (Table 3).

The landscape characteristics did not significantly influence the probability that a second annual breeding attempt took place in a site (mixed model: $P>0.35$ ). For individuals that switched nest-boxes between the first and second annual breeding attempts, the habitat characteristics of these two sites were not significantly different (signed rank test: male, $P>0.06$, female, $P>0.07$ ). On the other hand, the total length of roads inside the habitat had a 
Table 3 Mixed models analyses on the relationship between breeding parameters of the Barn Owl and different environmental variables characterising the landscape around 194 nest sites

\begin{tabular}{|c|c|c|c|c|c|c|c|}
\hline \multirow[t]{2}{*}{ Parameter } & \multirow[t]{2}{*}{ Variables } & \multicolumn{3}{|c|}{ First model } & \multicolumn{3}{|c|}{ Final model } \\
\hline & & $d f$ & $F$ & $P$ & $d f$ & $F$ & $P$ \\
\hline \multirow{11}{*}{$\begin{array}{l}\text { Site occupancy } \\
(0 / 1)\end{array}$} & Habitat component 1 (HC 1) & $1,2,051$ & 0.88 & 0.35 & & & $\mathrm{rd}$ \\
\hline & Habitat component 2 (HC 2) & $1,2,051$ & 0.30 & 0.58 & & & rd \\
\hline & Habitat component 3 (HC 3 ) & $1,2,051$ & 0.00 & 0.98 & & & rd \\
\hline & $\mathrm{X}$ Swiss coordinate & $1,2,051$ & 0.43 & 0.51 & & & rd \\
\hline & Y Swiss coordinate & $1,2,051$ & 0.43 & 0.51 & & & rd \\
\hline & Nest-box age & $1,2,051$ & 13.19 & 0.0003 & $1,2,054$ & 112.63 & $<0.0001$ \\
\hline & Used the year before & $1,2,051$ & 105.78 & $<0.0001$ & $1,2,054$ & 21.58 & $<0.0001$ \\
\hline & $\mathrm{X} * \mathrm{Y}$ Swiss coordinates & $1,2,051$ & 0.47 & 0.49 & & & rd \\
\hline & Used the year before ${ }^{*} \mathrm{HC} 1$ & $1,2,051$ & 0.52 & 0.47 & & & $\mathrm{rd}$ \\
\hline & Used the year before ${ }^{*} \mathrm{HC} 2$ & $1,2,051$ & 0.01 & 0.92 & & & rd \\
\hline & Used the year before ${ }^{*} \mathrm{HC} 3$ & $1,2,051$ & 0.09 & 0.76 & & & rd \\
\hline \multirow[t]{17}{*}{ Laying date } & Habitat component 1 (HC 1$)$ & 1,87 & 0.08 & 0.78 & & & $\mathrm{rd}$ \\
\hline & Habitat component 2 (HC 2) & 1,87 & 1.34 & 0.25 & & & rd \\
\hline & Habitat component 3 (HC 3) & 1,87 & 2.66 & 0.11 & & & $\mathrm{rd}$ \\
\hline & $\mathrm{X}$ Swiss coordinate & 1,87 & 0.63 & 0.43 & & & rd \\
\hline & Y Swiss coordinate & 1,87 & 0.57 & 0.45 & & & $\mathrm{rd}$ \\
\hline & Nest-box age & 1,87 & 3.56 & 0.062 & & & rd \\
\hline & Female age & 1,87 & 3.38 & 0.07 & & & $\mathrm{rd}$ \\
\hline & Male age & 1,87 & 15.89 & 0.0001 & 1,103 & 19.43 & $<0.0001$ \\
\hline & Female occupancy & 2,87 & 6.91 & 0.0016 & 2,103 & 13.70 & $<0.0001$ \\
\hline & Male occupancy & 2,87 & 9.31 & 0.0002 & 2,103 & 10.15 & $<0.0001$ \\
\hline & $\mathrm{X} * \mathrm{Y}$ Swiss coordinates & 1,87 & 0.64 & 0.43 & & & $\mathrm{rd}$ \\
\hline & Female occupancy $*$ HC 1 & 2,87 & 0.10 & 0.91 & & & rd \\
\hline & Female occupancy $*$ HC 2 & 2,87 & 1.29 & 0.28 & & & rd \\
\hline & Female occupancy $*$ HC 3 & 2,87 & 0.57 & 0.57 & & & rd \\
\hline & Male occupancy $*$ HC 1 & 2,87 & 0.01 & 0.99 & & & $\mathrm{rd}$ \\
\hline & Male occupancy * HC 2 & 2,87 & 0.66 & 0.52 & & & rd \\
\hline & Male occupancy * HC 3 & 2,87 & 3.32 & 0.041 & & & rd \\
\hline \multirow[t]{18}{*}{ Clutch size } & Habitat component 1 (HC 1) & 1,80 & 0.59 & 0.45 & & & $\mathrm{rd}$ \\
\hline & Habitat component 2 ( $\mathrm{HC} 2)$ & 1,80 & 0.92 & 0.34 & & & $\mathrm{rd}$ \\
\hline & Habitat component 3 (HC 3 ) & 1,80 & 0.79 & 0.38 & & & $\mathrm{rd}$ \\
\hline & $\mathrm{X}$ Swiss coordinate & 1,80 & 0.24 & 0.62 & & & $\mathrm{rd}$ \\
\hline & Y Swiss coordinate & 1,80 & 0.25 & 0.62 & & & $\mathrm{rd}$ \\
\hline & Nest-box age & 1,80 & 4.31 & 0.041 & & & $\mathrm{rd}$ \\
\hline & Female age & 1,80 & 9.76 & 0.0025 & 1,96 & 7.36 & 0.0079 \\
\hline & Male age & 1,80 & 3.46 & 0.066 & & & $\mathrm{rd}$ \\
\hline & Female occupancy & 2,80 & 1.04 & 0.36 & & & $\mathrm{rd}$ \\
\hline & Male occupancy & 2,80 & 2.54 & 0.085 & 2,96 & 7.22 & 0.0012 \\
\hline & Laying date & 1,80 & 4.02 & 0.048 & 1,96 & 8.54 & 0.0043 \\
\hline & $\mathrm{X} * \mathrm{Y}$ Swiss coordinates & 1,80 & 0.24 & 0.63 & & & $\mathrm{rd}$ \\
\hline & Female occupancy $*$ HC 1 & 2,80 & 0.64 & 0.53 & & & rd \\
\hline & Female occupancy $*$ HC 2 & 2,80 & 0.65 & 0.53 & & & $\mathrm{rd}$ \\
\hline & Female occupancy $*$ HC 3 & 2,80 & 2.18 & 0.12 & & & rd \\
\hline & Male occupancy $*$ HC 1 & 2,80 & 0.17 & 0.84 & & & rd \\
\hline & Male occupancy * HC 2 & 2,80 & 0.16 & 0.85 & & & rd \\
\hline & Male occupancy $*$ HC 3 & 2,80 & 0.51 & 0.60 & & & rd \\
\hline
\end{tabular}


Table 3 continued

\begin{tabular}{|c|c|c|c|c|c|c|c|}
\hline \multirow[t]{2}{*}{ Parameter } & \multirow[t]{2}{*}{ Variables } & \multicolumn{3}{|c|}{ First model } & \multicolumn{3}{|c|}{ Final model } \\
\hline & & $d f$ & $F$ & $P$ & $d f$ & $F$ & $P$ \\
\hline \multirow[t]{18}{*}{ Hatch size } & Habitat component 1 (HC 1) & 1,77 & 0.19 & 0.66 & & & rd \\
\hline & Habitat component 2 (HC 2) & 1,77 & 0.00 & 0.95 & & & $\mathrm{rd}$ \\
\hline & Habitat component 3 (HC 3 ) & 1,77 & 0.09 & 0.77 & & & $\mathrm{rd}$ \\
\hline & X Swiss coordinate & 1,77 & 0.59 & 0.44 & & & rd \\
\hline & Y Swiss coordinate & 1,77 & 0.70 & 0.41 & & & $\mathrm{rd}$ \\
\hline & Nest-box age & 1,77 & 1.91 & 0.17 & & & $\mathrm{rd}$ \\
\hline & Female age & 1,77 & 6.26 & 0.015 & 1,94 & 8.82 & 0.0038 \\
\hline & Male age & 1,77 & 6.95 & 0.01 & 1,94 & 22.23 & $<0.0001$ \\
\hline & Female occupancy & 2,77 & 0.11 & 0.90 & & & rd \\
\hline & Male occupancy & 2,77 & 0.84 & 0.44 & & & rd \\
\hline & Laying date & 1,77 & 1.07 & 0.30 & & & rd \\
\hline & $\mathrm{X} * \mathrm{Y}$ Swiss coordinates & 1,77 & 0.61 & 0.44 & & & rd \\
\hline & Female occupancy $*$ HC 1 & 2,77 & 0.83 & 0.44 & & & rd \\
\hline & Female occupancy $*$ HC 2 & 2,77 & 0.34 & 0.71 & & & rd \\
\hline & Female occupancy $*$ HC 3 & 2,77 & 0.67 & 0.52 & & & rd \\
\hline & Male occupancy $*$ HC 1 & 2,77 & 0.47 & 0.63 & & & rd \\
\hline & Male occupancy * HC 2 & 2,77 & 0.25 & 0.78 & & & rd \\
\hline & Male occupancy * HC 3 & 2,77 & 0.93 & 0.40 & & & rd \\
\hline \multirow[t]{18}{*}{ Fledglings } & Habitat component 1 (HC 1) & 1,84 & 0.02 & 0.88 & & & rd \\
\hline & Habitat component 2 (HC 2) & 1,84 & 2.70 & 0.1 & & & rd \\
\hline & Habitat component 3 (HC 3) & 1,84 & 3.77 & 0.055 & & & rd \\
\hline & X Swiss coordinate & 1,84 & 2.77 & 0.10 & & & rd \\
\hline & Y Swiss coordinate & 1,84 & 2.56 & 0.11 & & & rd \\
\hline & Nest-box age & 1,84 & 0.02 & 0.9 & & & rd \\
\hline & Female age & 1,84 & 1.36 & 0.25 & 1,102 & 5.62 & 0.0196 \\
\hline & Male age & 1,84 & 1.60 & 0.21 & & & $\mathrm{rd}$ \\
\hline & Female occupancy & 2,84 & 0.89 & 0.41 & & & $\mathrm{rd}$ \\
\hline & Male occupancy & 2,84 & 1.48 & 0.23 & & & rd \\
\hline & Laying date & 1,84 & 4.12 & 0.046 & & & $\mathrm{rd}$ \\
\hline & $\mathrm{X} * \mathrm{Y}$ Swiss coordinates & 1,84 & 2.76 & 0.10 & & & $\mathrm{rd}$ \\
\hline & Female occupancy $*$ HC 1 & 2,84 & 0.29 & 0.75 & & & rd \\
\hline & Female occupancy $*$ HC 2 & 2,84 & 0.59 & 0.56 & & & rd \\
\hline & Female occupancy $*$ HC 3 & 2,84 & 2.22 & 0.12 & & & rd \\
\hline & Male occupancy $*$ HC 1 & 2,84 & 0.21 & 0.81 & & & $\mathrm{rd}$ \\
\hline & Male occupancy * HC 2 & 2,84 & 2.18 & 0.12 & & & $\mathrm{rd}$ \\
\hline & Male occupancy $*$ HC 3 & 2,84 & 4.62 & 0.013 & & & $\mathrm{rd}$ \\
\hline \multirow[t]{11}{*}{ Egg volume } & Habitat component 1 (HC 1$)$ & 1,31 & 0.05 & 0.82 & & & rd \\
\hline & Habitat component 2 ( $\mathrm{HC} 2)$ & 1,31 & 0.01 & 0.91 & & & rd \\
\hline & Habitat component 3 (HC 3 ) & 1,31 & 0.12 & 0.74 & & & rd \\
\hline & X Swiss coordinate & 1,31 & 0.26 & 0.61 & & & rd \\
\hline & Y Swiss coordinate & 1,31 & 0.48 & 0.49 & & & rd \\
\hline & Nest-box age & 1,31 & 0.80 & 0.38 & & & rd \\
\hline & Female age & 1,31 & 0.16 & 0.69 & & & rd \\
\hline & Male age & 1,31 & 0.04 & 0.84 & & & rd \\
\hline & Female occupancy & 2,31 & 0.09 & 0.92 & & & rd \\
\hline & Male occupancy & 2,31 & 0.09 & 0.92 & & & $\mathrm{rd}$ \\
\hline & Laying date & 1,31 & 3.76 & 0.062 & & & $\mathrm{rd}$ \\
\hline
\end{tabular}


Table 3 continued

\begin{tabular}{|c|c|c|c|c|c|c|c|}
\hline \multirow[t]{2}{*}{ Parameter } & \multirow[t]{2}{*}{ Variables } & \multicolumn{3}{|c|}{ First model } & \multicolumn{3}{|c|}{ Final model } \\
\hline & & $d f$ & $F$ & $P$ & $d f$ & $F$ & $P$ \\
\hline & $\mathrm{X} * \mathrm{Y}$ Swiss coordinates & 1,31 & 0.31 & 0.58 & & & $\mathrm{rd}$ \\
\hline & Female occupancy $*$ HC 1 & 2,31 & 0.60 & 0.56 & & & rd \\
\hline & Female occupancy $*$ HC 2 & 2,31 & 0.63 & 0.54 & & & $\mathrm{rd}$ \\
\hline & Female occupancy $*$ HC 3 & 2,31 & 0.42 & 0.66 & & & rd \\
\hline & Male occupancy $*$ HC 1 & 2,31 & 0.86 & 0.43 & & & rd \\
\hline & Male occupancy * HC 2 & 2,31 & 3.10 & 0.059 & & & $\mathrm{rd}$ \\
\hline & Male occupancy $*$ HC 3 & 2,31 & 0.32 & 0.73 & & & rd \\
\hline
\end{tabular}

In first models, the terms "habitat components" were the main variables. Covariates were introduced because they where known to affect breeding parameters. The variables 'female occupancy' and 'male occupancy' indicate whether birds bred in the site in the past $(1=$ first reproduction in the site; 2 = have already bred in the site the year before; $3=$ have already bred in the site but not the year before). To control for pseudo-replication, year, nest site and identity of breeding adults were added in models as random factors. Non-significant interactions and variables were removed step by step from the first model to obtain the final model. Significant variables are written in bold

* Indicates interaction, $d f$ degrees of freedom, $r d$ removed

negative effect on the occupancy of nest-boxes, with a significantly smaller occupancy of those nest-boxes surrounded by a greater number of roads (GLIMMIX with year and site as two random variables: $F_{1,147.1}=9.23$, $P=0.0028)$. This variable was not significantly associated with other breeding parameters.

\section{Discussion}

Using GIS methods, we assessed the relationships between landscape characteristics measured around nest-sites and breeding performance in a Swiss Barn Owl population from 1987 to 2009. To link landscape characteristics quantified in 2009 and information on breeding performance collected over the 23 years, we assumed that the habitat did not change considerably during this period. Significant modifications in agricultural practices and landscape have occurred between 1950 and 1980 with the occurrence of new technical methods (Lundstrom 2002), but stabilised over the period 1984-1995 (SIGMAPLAN 2001). This assumption is supported by the observation that the proportion of a given prey species in a given nest site was significantly repeatable over the years in the study area (Roulin 2004b). The fact that the diet analysis and our habitat variables were associated proves that the landscape classification, using GIS methods complemented by fieldwork, was reliable and well reflects how Barn Owls exploit their habitat.

Landscape influence on breeding success

No significant relationship between the habitat variables and breeding performances of Swiss Barn Owls was found despite the large data set. Our results are similar to those of
Meek et al. (2009) who obtained relatively few correlations between land cover categories and aspects of breeding performances in England over a 14-year period. These results could be explained by the fact that, in both studies, variations between home range habitats were too small to detect clear effects on breeding parameters. The agricultural intensification has led to a homogenisation of the landscape pattern (Lundstrom 2002). Hedges have been removed and seminatural habitats exploited to produce larger fields, affecting the biodiversity in the agricultural landscape (Newton 2004). Future studies should be performed at a larger spatial scale to compare the breeding parameters of owls living in agricultural-dominated environments and semi-natural landscapes as shown in the UK study where owls breeding in areas of semi-natural grassland produced more offspring than those breeding in arable or pastoral areas (Leech et al. 2009).

An alternative interpretation for the absence of relationship between habitat characteristics and breeding success is that nest-boxes were not randomly located inside the study area. Nest-boxes were put in barns according to their availability. Therefore, Barn Owls could not really choose their 'preferred' habitats inside the study area. They had the choice of sites with quite similar habitats that we find around barns in the Swiss countryside. It converges with the previous explanation that prey availability is relatively similar between the different breeding sites. Therefore, Barn Owls adapt to their habitats (Meek et al. 2009) and will always find suitable foraging habitats in an environment such as in western Switzerland. This flexibility is supported by the feeding strategy of the Barn Owl. Tores et al. (2005) showed that Barn Owls are selective-opportunist predators: "although Barn Owls select one prey species at a certain period of time, they exhibit an opportunistic feature in their ability to easily switch between prey items in their diet". We can conclude from this that Barn Owls are opportunistic 
and can easily adapt to their environment. In spite of the fact that Barn Owls do not seem to choose specific habitats in agriculture, they showed a reaction against roads. Indeed, traffic casualty negatively affects Barn Owl populations (Taylor 1994; de Bruijn 1994; Roulin 2002a). A last possibility to explain the lack of strong associations between landscape characteristics and breeding parameters is that we may have missed the relevant habitat variables.

\section{Other influences on breeding success}

Breeding parameters were associated with female and male age. As reported by Altwegg et al. (2007), clutch size was not significantly associated with female age but decreased with increasing male age. Egg volume was maximal in individuals aged 2-5 years, and brood size at fledging was highest in males aged 2-5 years while in females this reproductive parameter showed a linear increase with age. The proportion of eggs that failed to hatch was not related to female age but increased with male age. Although only females assume incubation duties, relationships between clutch size, hatching success and male age are not surprising because during incubation only the male hunts and thereby feeds his mate (Durant et al. 2004). Correlations between breeding parameters and male age can be explained by age-related investment in reproduction, fertility and experience. A role of experience is consistent with the observation that breeding success was higher in individuals that previously bred in a nest site compared to owls that bred for the first time in a site. A better knowledge of the breeding site landscape may enable it to be exploited more efficiently, which may, in turn, enhance breeding success. This result is intuitive and is strengthened by the sedentary nature of the Barn Owl (Shaw 1994; Taylor 1994; Marti 1999).

\section{Diet and prey accessibility}

The most frequent prey of the Barn Owl in the study area, common voles (M. arvalis; Arlettaz et al. 2010), made up, on average $74 \%$ of the Barn Owl diet. M. arvalis was more frequently preyed on in territories rich in cereal fields and where woodlands were less abundant. This result supports that of Arlettaz et al. (2010), who found that Barn Owls forage more often in cereal fields and grassland although these habitat types carry a low prey density. Thus, the pellet analysis reflects more the foraging habitat and the accessibility of prey than the abundance of small mammals in the territory as was also found in Hungary (Horváth et al. 2005). This tendency was also found for numerous species of farmland birds (Atkinson et al. 2005). We found significant relationships between the habitat landscape and the proportion of common and water voles but not wood mice and shrews, perhaps because the sample size was relatively low (20 nest-boxes).

Implications for conservation of the Barn Owl

From a conservation point of view, several factors are known to affect Barn Owl populations (de Bruijn 1994; Roulin 2002a). These factors can be classified in three main groups. The first group contains stochastic events such as fluctuation of the weather (Zuberogoitia 2000), snow cover (Altwegg et al. 2006), mean annual temperature (Altwegg et al. 2003), and fluctuation of food abundance (Klok and de Roos 2007). The second group are deaths caused by human activities, such as traffic casualties and pesticides (Taylor 1994). The last group covers the loss of breeding sites and habitat changes on farmland (Martinez and Zuberogoitia 2004). In this study, we underlined that landscape habitats do not seem to have strong effects on the breeding success of a Barn Owl population living in a stabilised farmland environment in Switzerland. Thus, we might target the conservation of the species on the following three measures: (1) the plantation of high hedges on both sides of main roads to force owls to fly higher and thus to reduce car collisions (Erritzoe et al. 2003; but obviously this may put many species living or using these hedges at risk); (2) the placement of additional nest-boxes in order to create new breeding sites, in consideration of the number of roads around the site; and (3) the creation of more ecological compensation areas (ECA) such as wildflower areas and the management of open foraging corridors around these food reservoirs to render these landscapes exploitable by the owls (Arlettaz et al. 2010; Aschwanden et al. 2005).

\section{Zusammenfassung}

Habitat, Brutleistung, Nahrung und individuelles Alter von Schweizer Schleiereulen Tyto alba

Die Intensivierung der Landwirtschaft in den vergangenen 50 Jahren hat die Struktur der europäischen Landschaften homogenisiert und zum Rückgang der Vogelpopulationen beigetragen. Um den Schutz der Schleiereule Tyto alba zu verbessern, haben wir den Einfluss der Landschaftsstruktur auf den Bruterfolg in der Westschweiz untersucht. Die Analysen berücksichtigen Brutparameter über 23 Jahren aus einer durch intensive Landwirtschaft dominierten Landschaft. Mithilfe eines geografischen Informationssystems (GIS) wurden Landschaftscharakteristika rund um 194 Brutorte beschrieben. Unsere Analysen zeigen, dass die Besetzung der Brutkästen, Legedatum, Größe des Geleges und der Brut, Eivolumen und die Wahrscheinlichkeit 
einer Zweitbrut mit keiner der acht wichtigsten Landschaftsparametern (Landwirtschaftsland, Wald, Siedlungsraum, Hecken, Getreide, Zuckerrübe, Mais und Wiese) signifikant zusammenhängen. Allerdings nimmt die Wahrscheinlichkeit der Besetzung eines Nistkastens durch ein Brutpaar ab mit der Zahl Straßen, die die Nistkasten umgeben. Das Fehlen eines starken Zusammenhangs von Habitateigenschaften mit Brutparametern weist darauf hin, dass die Verfügbarkeit von Beute zwischen den unterschiedlichen Brutplätzen relativ ähnlich ist. In unserem Untersuchungsgebiet können Schleiereulen immer passende Habitate zur Futtersuche um die meisten Nistkästen finden.

Acknowledgments We thank Bettina Almasi, the late Martin Epars and Henri Etter for help with collecting field data. We also thank Simon Birrer, Lukas Jenni, Motti Charter, Iñigo Zuberogoitia, Meredith Blake and an anonymous referee for helpful comments on an early version of the manuscript and Pierre Bize for statistical advice. The Swiss National Science Foundation (grants no. PPOA102913 and 31003A_120517 to A. Roulin) supported this study financially.

\section{References}

Altwegg R, Roulin A, Kestenholz M, Jenni L (2003) Variation and covariation in survival, dispersal, and population size in barn owls Tyto alba. J Anim Ecol 72:391-399

Altwegg R, Roulin A, Kestenholz M, Jenni L (2006) Demographic effects of extreme winter weather in the barn owl. Oecologia 149:44-51

Altwegg R, Schaub M, Roulin A (2007) Age-specific fitness components and their temporal variation in the barn owl. Am Nat 169:47-61

Andries AM, Gulinck H, Herremans M (1994) Spatial modelling of the barn owl Tyto alba habitat using landscape characteristics derived from SPOT data. Ecography 17:278-287

Arlettaz R, Krähenbühl M, Almasi B, Roulin A, Schaub M (2010) Wildflower areas within revitalized agricultural matrices boost small mammal populations but not breeding barn owls. J Ornithol. doi:10.1007/s10336-009-0485-0

Aschwanden J, Birrer S, Jenni L (2005) Are ecological compensation areas attractive hunting sites for common kestrels (Falco tinnunculus) and long-eared owls (Asio otus)? J Ornithol 146:279-286

Aschwanden J, Holzgang O, Jenni L (2007) Importance of ecological compensation areas for small mammals in intensively farmed areas. Wildl Biol 13:150-158

Atkinson PW, Fuller RJ, Vickery JA, Conway GJ, Tallowin JRB, Smith REN, Haysom KA, Ings TC, Asteraki EJ, Brown VK (2005) Influence of agricultural management, sward structure and food resources on grassland field use by birds in lowland England. J Appl Ecol 42:932-942

Avenant NL (2005) barn owl pellets: a useful tool for monitoring small mammals communities? Belg J Zool 135:39-43

Benton TG, Vickery JA, Wilson JD (2003) Farmland biodiversity: is habitat heterogeneity the key? Trends Ecol Evol 18:182-188

Billeter R, Liira J, Bailey D, Bugter R, Arens P, Augenstein I, Aviron S et al (2008) Indicators for biodiversity in agricultural landscapes: a pan-European study. J Appl Ecol 45:141-150
Bond G, Burnside NG, Metcalfe DJ, Scott DM, Blamire J (2005) The effects of land-use and landscape structure on barn owl (Tyto alba) breeding success in southern England, UK. Landscape Ecol 20:555-566

Bontzorlos VA, Peris SJ, Vlachos CG, Bakaloudis DE (2005) The diet of barn owl in the agricultural landscapes of central Greece. Folia Zool 54:99-110

Butet A, Paillat G, Delettre Y (2006) Factors driving small rodents assemblages from field boundaries in agricultural landscapes of western France. Landscape Ecol 21:449-461

Chaline J, Baudvin H, Jammot D, Saint Girons MC (1974) Les proies des rapaces (petits mammifères et leur environnement). Doin, Paris

De Bruijn O (1994) Population ecology and conservation of the barn owl Tyto alba in farmland habitats in Liemers and Achterhoek (The Netherlands). Ardea 82:1-109

de la Pena NM, Butet A, Delettre Y, Paillat G, Morant P, Le Du L, Burel F (2003) Response of the small mammal community to changes in western French agricultural landscapes. Landscape Ecol 18:265-278

Donald PF, Green RE, Heath MF (2001) Agricultural intensification and the collapse of Europe's farmland bird populations. Proc R Soc Lond B 268:25-29

Durant JM, Gendner JP, Handrich Y (2004) Should I brood or should I hunt: a female barn owl's dilemma. Can J Zool 82:1011-1016

Erritzoe J, Mazgajski TD, Rejt L (2003) Bird casualties on European roads-a review. Acta Ornithol 38:77-93

Garcia-Ripolles C, Lopez-Lopez P, Garcia-Lopez F, Aguilar JM, Verdejo J (2005) Modelling nesting habitat preferences of Eurasian griffon vulture Gyps fulvus in eastern Iberian Peninsula. Ardeola 52:287-304

Horváth G, Dániel M, Tamás N, Sándor C (2005) Landscape ecological analysis of barn owl pellet data from the Drava lowlands, Hungary. Natura Somogyiensis 7:179-189

Kasprzykowski Z, Golawski A (2006) Habitat use of the barn owl Tyto alba and the little owl Athene noctua in central-eastern Poland. Biol Lett 43:33-39

Keller V, Zbinden N, Schmid H, Volet B (2001) Liste Rouge des oiseaux nicheurs menacés de Suisse. Edit. Office fédéral de l'environnement, des forêts et du paysage, Berne et Station ornithologique suisse, Sempach. OFEFP-Série: L'environnement pratique. p. 57

Klok C, de Roos AM (2007) Effects of vole fluctuations on the population dynamics of the barn owl Tyto alba. Acta Biotheor $55: 227-241$

Leech DI, Shawyer CR, Barimore CJ, Crick HQP (2009) The barn owl monitoring programme: establishing a protocol to assess temporal and spatial variation in productivity at a national scale. Ardea 97:421-428

Lopez-Lopez P, Garcia-Ripolles C, Aguilar JM, Garcia-Lopez F, Verdejo J (2006) Modelling breeding habitat preferences of Bonelli's eagle (Hieraatus fasciatus) in relation to topography, disturbance, climate and land use at different spatial scales. J Ornithol 147:97-106

Love RA, Webbon C, Glue DE, Harris S (2000) Changes in the food of British barn owls (Tyto alba) between 1974 and 1997. Mammal Rev 30:107-129

Lundstrom C (2002) Dynamique du paysage rural de la partie nordouest de la Suisse. Une analyse pour comprendre la variation des populations du lièvre brun (Lepus europaeus). Ecole Polytechnique Fédérale de Lausanne, Lausanne. 158 pp

Marti CD (1999) Natal and breeding dispersal in barn owls. J Raptor Res 33:181-189

Martinez JA, Zuberogoitia I (2004) Habitat preferences and causes of population decline for barn owls Tyto alba: a multi-scale approach. Ardeola 51:303-317 
Maumary L, Vallotton L, Knaus P (2007) Les oiseaux de Suisse. Station ornithologique Suisse, Sempach, et Nos oiseaux, Montmollin

Meek WR, Burman PJ, Nowakowski M, Sparks TH, Hill RA, Swetnam RD, Burman NJ (2009) Habitat does not influence breeding performance in a long-term barn owl Tyto alba study. Bird Study 56:369-380

Michel N, Burel F, Butet A (2006) How does landscape use influence small mammal diversity, abundance and biomass in hedgerow networks of farming landscapes? Acta Oecol 30:11-20

Newton I (2004) The recent declines of farmland bird populations in Britain: an appraisal of causal factors and conservation actions. Ibis 146:579-600

Rodriguez C, Peris SJ (2007) Habitat associations of small mammals in farmed landscapes: implications for agri-environmental schemes. Anim Biol 57:301-314

Roulin A (2002a) Tyto alba barn owl. BWP 4:115-138

Roulin A (2002b) Offspring desertion by double-brooded female barn owls Tyto alba. Auk 119:515-519

Roulin A (2004a) The function of food stores in bird nests: observations and experiments in the barn owl Tyto alba. Ardea 92:69-78

Roulin A (2004b) Covariation between plumage colour polymorphism and diet in the barn owl Tyto alba. Ibis 146:509-517

Salvati L, Ranazzi L, Manganaro A (2002) Habitat preferences, breeding success and diet of the barn owl (Tyto alba) in Rome: urban versus rural territories. J Raptor Res 36:224-228
Seamans ME, Gutierrez RJ (2007) Habitat selection in a changing environment: the relationship between habitat alteration and spotted owl territory occupancy and breeding dispersal. Condor 109:566-576

Shaw G (1994) A ten year study of barn owl conservation in conifer forests. Scott Birds 17:187-191

SIGMAPLAN/METRON/METEOTEST (2001) Le paysage sous pression: 1984-1995. Office fédéral du développement territorial/Office fédéral de l'environnement, des forêts et du paysage, Berne

Stoate C, Baldi A, Beja P, Boatman ND, Herzon I, van Doorn A, de Snoo GR, Rakosy L, Ramwell C (2009) Ecological impacts of early 21 st century agricultural change in Europe-a review. J Environ Manage 91:22-46

Taylor IR (1993) Age and sex determination of barn owls Tyto alba alba. Ring Migr 14:94-102

Taylor IR (1994) barn owls: predator-prey relationships and conservation. Cambridge University Press, Cambridge

Tores M, Motro Y, Motro U, Yom-Tov Y (2005) The barn owl-a selective opportunist predator. Isr J Zool 51:349-360

Tworek S (2002) Different bird strategies and their responses to habitat changes in an agricultural landscape. Ecol Res 17: 339-359

Zuberogoitia I (2000) La influencia de los factores meteorologicos sobre el exito reproductor de la lechuza comun. Ardeola 47:49-56 